\title{
Politics of Antitrust Law
}

\author{
Rupprecht Podszun
}

Published online: 31 May 2016

(C) Max Planck Institute for Innovation and Competition, Munich 2016

For antitrust lawyers, the U.S. elections have a meaning beyond general politics since the Commander-in-Chief not only rules in military conflicts but also is the ultimate head of the Antitrust Division in the Department of Justice where some essential parts of antitrust law are enforced. It may be unique that in the 2016 primaries a candidate with first-hand experience of antitrust enforcement has emerged: Donald Trump. In 1988 he was charged with having violated premerger notification requirements of the Hart-Scott-Rodino Act. Trump settled with a payment of $\$ 750,000$. As an owner of a football team, Trump challenged the National Football League in a case of monopolization, winning in substance but being awarded damages of only three dollars. Later, Trump himself was accused of monopolization in an Atlantic City hotel casino case. Trump won after a timeconsuming legal battle. It is not predictable how these experiences would pay off in case of a Trump election victory. Hillary Clinton, on the other side, has been driven to the left by Bernie Sanders, and during the election campaign so far, she has cultivated a rhetoric that promises tougher antitrust enforcement in key sectors. She has stated she would hire "aggressive regulators" for the task.

The speculation on how the key positions in antitrust are filled and whether the new Administration will initiate big cases sheds light on the issue of the politicization of antitrust laws around the world. Every antitrust orientation has a political side to it: It matters whether fairness or freedom or efficiencies or development are defined as the ultimate goals of enforcement. Yet, the interest of politicians in antitrust law and the political discussion of aims and tools vary. It seems that at present antitrust is back on the political agenda. For researchers and practitioners this is a sign to be on guard.

R. Podszun $(\square)$

Professor of Civil Law

University of Bayreuth; Max Planck Institute for Innovation and Competition, Bayreuth, Germany

e-mail: LS-Podszun@uni-bayreuth.de 
Some examples: Commentators watching the Chinese enforcement of the AntiMonopoly Law report that national political interests carry more weight nowadays. The European Commission's never-ending Google story seems to be more of a political affair than a legal one. In Germany, the government - in a rare move recently overruled the national competition agency on the grounds of greater political interests in a high-profile supermarket merger, allowing the parties to proceed. The President of Ivory Coast has spectacularly opened up power and water markets for competition. Parliamentary committees in several countries have dealt with antitrust matters in a political fashion in recent months. And even on the international stage, there may be a comeback for competition law through trade agreements.

Antitrust law shares this new prominence with copyright and patent law - two other fields of law where decisions have become much more politically controversial.

Three reasons may be identified why this political interest is awakening: First, digitalization is a game-changer in the economy. The arising conflicts call for new legal answers. Germany, for instance, will amend its antitrust code this year in order to integrate rules for the digital economy. Secondly, the aims of antitrust law are calibrated anew from time to time. After years of a strict focus on certain efficiencies, the pendulum is swinging back to more freedom- and fairness-related goals. Thirdly, it seems that politicians are turning to a tool that some see as the last remaining sword to fight the excesses of capitalism. Other means of state intervention fail: The influence of politics on the economy has declined; undertakings are now more global, fast moving, virtual and finance-driven. This makes it difficult to design new rules - not to speak of the complex political processes that make the regulation of business a tough game. The relatively open norms of antitrust law and the well-established institutions that are used to set record-high fines are instrumental in filling this gap.

From a scholarly perspective, the heightened interest in one's own field of law comes with mixed feelings. On the one hand, it is possible to raise awareness, get new resources for competition agencies, and readjust policies with impulses from democratic processes. On the other hand, unbiased enforcement and a solely professional or technical approach have always been the assets of specialized authorities. A clear line may be drawn for cases and rules: It is not for politicians or the legislator to meddle with individual cases. The task for lawmakers is to lead the discourse on what economy we want and what we see as the necessary rules to make the market economy work. These questions are coming up with new vigor: The success of Bernie Sanders with younger voters in the U.S. may be a symbol for changing views in the electorate (not just in the U.S.) on these questions.

The agenda for researchers vis-à-vis this development may have three aspects: to preserve independence, identify legal fundamentals, and disclose normative assumptions.

On independence: The European Commission (itself a political body that takes the decisions in EU antitrust matters) is suggesting reforms in order to make national competition agencies more independent. Those interested in an unbiased enforcement should support this agenda. This may mean tough institutional reforms, 
yet the Netherlands and the UK have proved that the fundamental restructuring of competition agencies is possible.

On fundamentals: In recent decisions, the Court of Justice of the EU has made clear that it will pursue a rights-oriented approach. Antitrust enforcement needs to respect the Charter of Fundamental Rights. This may seem self evident, yet "taking rights seriously" may come with surprises for established doctrine. Similarly, international law, trade treaties for instance, restrict the freedom to change antitrust law on the national level. Research needs to identify such defining fundamentals.

On normative assumptions: Antitrust law will always depend upon normative value judgments. For instance, there is no clear indication of what an abuse of market power is. Hence, ultimately, this is an on-going discourse case by case. Yet, some tools and rules have normative assumptions that need to be revealed. Otherwise, the use of a certain, seemingly neutral tool in market definition for instance takes enforcers on a path that they can hardly leave again. If scholars do not detect these normative assumptions and suggest diverse approaches, path dependencies will abound.

These comments may read like a statement on the high-profile cases that are taken up by the European Commission. Yet, narrowing the perspective on these cases would not do justice to antitrust law. Fortunately, wise friends of competition have built in a mechanism that brings in anarchic power to a planned field of law: private enforcement. No one will be able to control the politics of an antitrust plaintiff in Atlantic City or a judge in the Düsseldorf District Court. For the discovery procedures of economic regulation, this is all the better. 